\title{
Development of an Algorithm for Tip-related Artifacts Identification in AFM Biological Film Imaging
}

\author{
Rubens Bernardes-Filho* and Odilio Benedito Garrido de Assis \\ Embrapa Instrumentação Agropecuária; Rua XV de novembro, 1452; C. P. 741; 13560-970; \\ rubens@cnpdia.embrapa.br; São Carlos - SP - Brasil
}

\begin{abstract}
One major drawback identified in atomic force microscopy imaging is the dependence of the image's precision on the shape of the probe tip. In this paper a simple algorithm is proposed to provide artifact identification signaling in-situ tip features in atomic force microscopy images. The base of the identifications lied when the angle formed between two scanned points was kept the same as the tip sweeps a certain length of the sample. The potential of the described method was illustrated on a chitosan polysaccharide film. The images produced were compared to evaluate tip-artifact regions. This algorithm showed promise as a tool in the measurement and characterization fields to separate true images from artificial images in probe microscopy.
\end{abstract}

Key words: Probe microscopy, AFM, images tip artifacts, biological film

\section{INTRODUCTION}

The instrumentation for nano-scale imaging has shown a great advancement with the advent of the scanning probe microscopy. In particular the atomic force microscopy (AFM), developed in the mid-1980s, has been increasingly drawing attention as an entirely new approach in the study of the surface topography of biological specimens (Siperko and Landis, 1993; Saho et al., 1996; Kasas et al., 1997). This microscopy has the ability to perform quantitative in situ real-time imaging of surface in a variety of environments as air, liquid or vacuum (Weisenhorn, et al. 1989; Drake et al., 1989). The instrument flexibility accounts for its use in many biology and biochemistry field, by probing the structures and systems, including biomolecules, biomembranes, protein films and crystals, and living cells at spatial resolution. (Erlandsson et al, 1992; Herrmann, et al., 1997,
Hansma, et al., 1997; Assis, et al. 1998). Despite of the apparent simplicity of imaging from the probe microscopes, the resultant topographies are subject of some artifacts that should be detected and interpreted for reliable conclusions. In particular for biological assessment, artifacts generated should be clearly identified for avoiding misinterpretation. In this work an algorithm was developed which enabled the detection of tip artifact and here presented in a biological film as illustration.

\section{AFM BASICS}

The AFM imaging is obtained by monitoring the position of a small spring-like probe maintained very close to the surface, mapping the sample's point to point. This is called "the local probe method" (Odin, et al., 1994), since it is supposed

\footnotetext{
*Author for correspondence
} 
to probe the local properties of the surface (Fig. 1). The probe, called "tip", is placed on the extremity of a flexible light reflective cantilever that is between 100 and 200 micrometers in length, where the interaction between the tip and the surface contributes to the cantilever deflection. Several interatomic forces act between the apex of the tip and atoms in a sample as the tip is scanned over the surface (Weisenhon, 1989; Herrmann, et al., 1997). A laser beam is projected on the cantilever, where the dislocation due to the tip deflection or bend, deflects the light, which is monitored by a photoelectric detector. The floating signal allows a computer to generate a map of surface topography. Through a feedback system, a fine-motion piezoelectric scanner is used to carry precision motion of the sample that is needed to generate the topographical image. Fig. 2 illustrates the basic AFM system.

By using an appropriated software control, the forces between the probe and surface can be controlled, which in turn controls motions of the probe tip. Basically, two electronic feedback loops can be inputted: A possible mode of operation is the 'contact-mode', where the tip almost touches the sample, in this case the repulsive forces dominate the tip-sample interaction. In contact mode the dragging motion of the tip exerts a lateral force on the surface that can push around any adsorbed particles that are encountered, preventing imaging of particles in their natural arrangement on the surface.

Another possibility is enabling the tip to maintain either a constant force or constant height above the sample, where the piezoelectric transducer monitors real time height deviation, producing an image contrast. This mode of operation generally reduces noise in images, but it requires the tip to be scanned at higher speeds.

None of the operation modes, however, are free to avoid interaction between tip and sample, such as crashing during scanning, water adsorption on the tip or contamination by the sample, what invariable introduce artifacts during imaging.

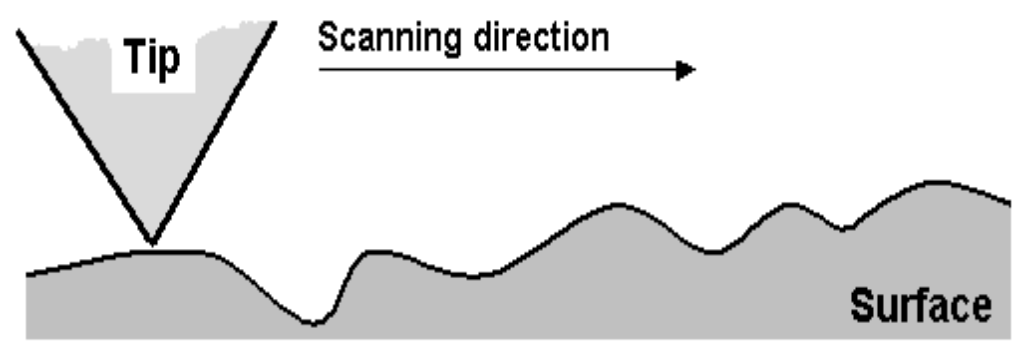

Figure 1 - Illustration of a tip scanning a sample surface.

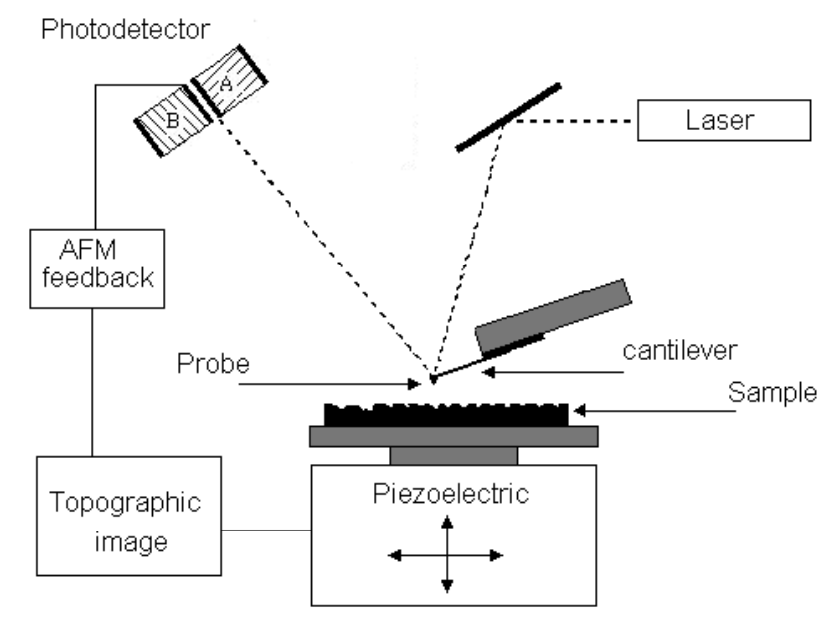

Figure 2 - Schematic diagram of an AFM set up apparatus basic components. 


\section{TIP-ARTIFACT IN AFM IMAGING}

The main artifact generated by AFM is the 'tipimage' effect. Protrusions and tiny holes in the surface that are sharper than the profiling tip, can produce fake images that are more a profile of the tip than of the sample. Fig. 3 shows a single line that is illustrating the generated image of two typical irregularities. In the parts of the surface where the tip touches the sample's wall, the 'tipimage' effect obviously will predominate. Parts of resultant image are the consequence of the 'sliding' of the tip over the surface. In biological samples, another common tip effect concerns the relative dimension of the scanned sample compared to the tip. These are frequent in bacteria and DNA like specimens. Fig. 4 illustrates this condition. In these, the tip interacts laterally with the specimen 'jumping' it. The actual specimen height $\mathbf{h}$ is replaced by an unreal profile with height $\mathbf{H}$. That is better understood in a real case example, i.e., a DNA image AFM generated and through an analyzed crossed line (Fig. 5), presenting an artificial topography (BernardesFilho, 1999).

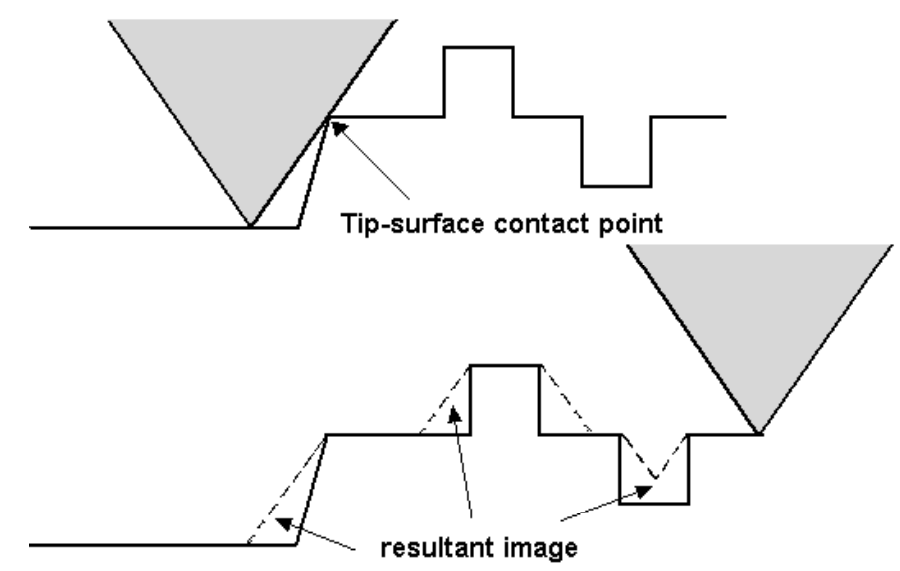

Figure 3 - Resultant image artifact due to tip dimension. Note that in the features of the surface the image reflect the tip angles.

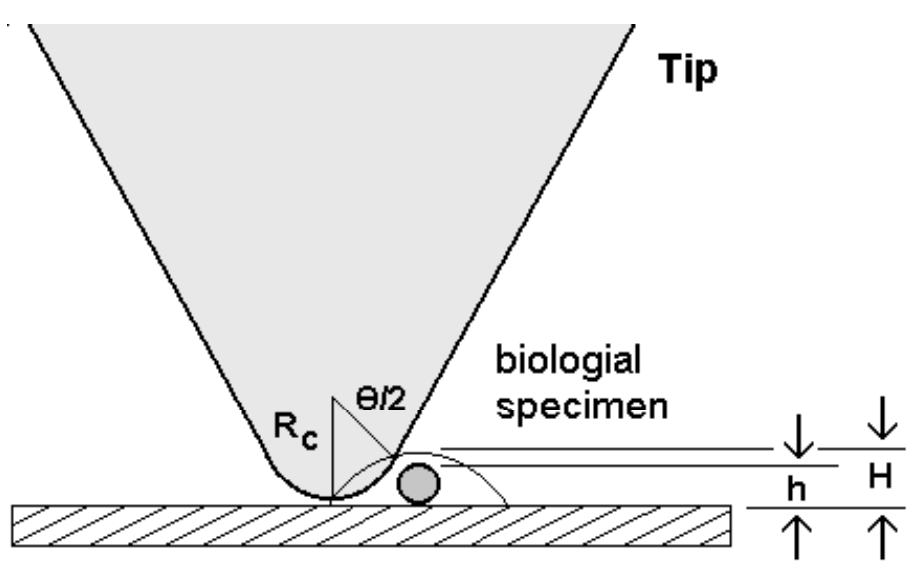

Figure 4 - Schematic proportion between tiny biological samples as G-wire DNA (silhouette) and AFM tip. Dimensional model after Vesenka et al., 1996. 

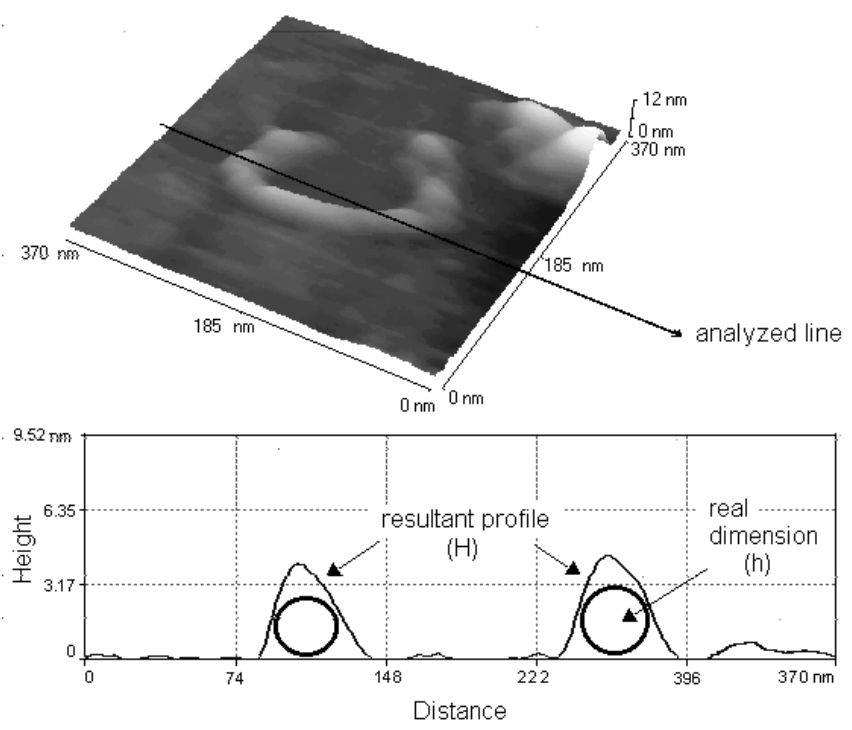

Figure 5 - A DNA scanned by AFM and a cross-section resultant (analyzed line) with an artificial topography (Bernardes-Filho et al., 1997).

\section{THE PROPOSED ALGORITHM FOR DIRECT ARTIFACT IDENTIFICATION}

The original microscopic system has resident software that works as intermediate to the scanning process and image generation. The specific file in this software to generate image consisted in a called "header" part, which is the preliminary information lines. In the sequence routine, a data matrix is set which describes features such as linear dimension and height of each scanned point. The algorithm extracts the scanned information and transfers the data into a new matrix where the image resolution is finally defined. In that matrix, a function performs a comparison between two images: a 'real' and a 'raw' where the tip geometry information is previously inputted. For example, if the resolution is 300 by 300 bytes ("carrier return"), the generated image will present $300^{2}$ dots (Tesini et al., 1998). Such turns easy the manipulation of the figure features, allowing clear identification of artifacts in each repeated array of the resultant image.

\section{PRACTICAL EXAMPLE}

AFM TopoMetrix Discover TMX 2010 system, with a pyramidal commercial available $\mathrm{Si}_{3} \mathrm{Ni}_{4}$ tip, with $4 \mu \mathrm{m}$ high $\mathrm{X} 4 \mu \mathrm{m}$ base dimensions was used. The biological sample was a chitosan film immobilized onto a cleaved mica support. Chitosan is a polysaccharide derived from chitin formed by repeating units of beta (1-4) 2-amino-2deoxy-D- glucose (or D-glucosamine) and its structure is similar to cellulose (except the hydroxy groups in position 2 replaced by acetylamino groups). Chitosan is an antibacterial and antifungal polymer and has been recently pointed as a natural fatter trapper and a cholesterol controller (Deuchi et al., 1994; Kanauchi et al, 1995). Films of chitosan have been proposed as artificial skin (Nettles, 2001) and smart bandages for controlled drug release (Howling, et al., 2002). The films of chitosan, from Fluka, were obtained by direct immersing of the mica surfaces in the rich solution $\left(10^{-3} \mathrm{M}, \mathrm{pH}=3\right)$, for three minutes and rinsed in pure water. Details of film preparation can be found elsewhere (Assis et al., 2002). The image was generated in air, in contact mode, using "The Khoros" (Image Analyzer Software) in UNIX platform.

\section{SOLUTION OF AREA CALCULATION PROBLEM AND ARTIFACT CAPTURE}

The calculation of the scanned area is solved by vectorial analysis. If we take 3 points in space, the relative position between them is feasible to be put as in Fig. 6. Where $\mathrm{P}=\left(\mathrm{P}_{1}, \mathrm{P}_{2}, \mathrm{P}_{3}\right)$ and $\mathrm{W}=$ $\left(\mathrm{W}_{1}, \mathrm{~W}_{2}, \mathrm{~W}_{3}\right)$. 
(a)

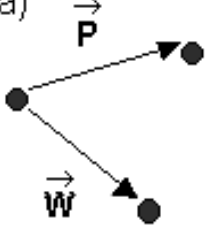

(b)

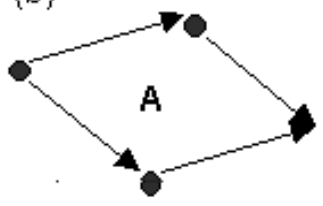

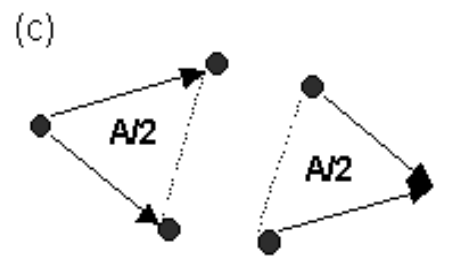

Figure 6 - (a) Spatial definition of vectors P and W. (b) Parallelogram formed by $\mathrm{P} \mathrm{X} \mathrm{W}$, which is composed of 2 similar triangles (c).

It is known that:

$|\mathbf{P} \times \mathbf{W}|=\mathrm{A}=$ Parallelogram area.

Such area can be estimated twofold (Arfken et a.l, 2000); as:

$$
|\mathbf{P} \times \mathbf{W}|=|\mathbf{P}| .|\mathbf{W}| \cdot \operatorname{sen}(\alpha)
$$

where $\alpha$ is the angle between the two vectors, or by scalar product of vectors, then:

$\mathbf{A}=\left(\mathrm{P}_{2} \mathrm{~W}_{3}-\mathrm{P}_{3} \mathrm{~W}_{2}\right) \cdot \mathbf{i}+\left(\mathrm{P}_{3} \mathrm{~W}_{1}-\mathrm{P}_{1} \mathrm{~W}_{3}\right) \cdot \mathbf{j}+\left(\mathrm{P}_{1} \mathrm{~W}_{2}-\mathrm{P}_{2}\right.$ $\left.\mathrm{W}_{1}\right) \cdot \mathbf{k}$

Where $\mathbf{i}, \mathbf{j}$ and $\mathbf{k}$ are orthonormal vectors.

Both expressions present the area A of Fig. 6(b). So, each triangle in the plane is formed by 3 points and has the area:

$|\mathbf{P} \times \mathbf{W}| \div \mathbf{2}$, that is $\mathrm{A} \div \mathbf{2}$, as presented in Fig. 6 (c) .

Hence, it is possible to set a calculus routine identifying areas in the scanned image where artifacts are probable to occur (Tesini et al., 1998). The base of the identifications is when the angle formed between two scanned points is kept the same as the tip sweeps a certain length of the sample. The amount of identified with the same angle is than marked in the generated image, as put in Fig. 7.

The following image, the chitosan film, (Fig. 8a) is the recorded topographic image generated with no algorithm application. In Fig. 8(b) it is the same image horizontally scanned where the dots indicates positions on the image where the tipinclination angles are the same, thereby a candidate for tip-artifacts. The same procedure is done for angle identification over vertical or through a combination of both direction scanning. The resultant combination of images allows the artifacts identification by plotting black regions in the scan direction, i.e., indicates regions of interactions between the edge of the pyramidal tip and the organic film surface.

In other words, the marked regions in Fig. 8 could be considered as an unreal representation of the local surface, since the punctual inclinations on surface were similar to the angle of pyramid formed by the cantilever tip. Such artifact outcome from contact between the sample surfaces with the lateral edges of the tip, with actual inclination varied from tip to tip model.

In function of its pyramidal shape, the algorithm was programmed to perform two scans, one in vertical directions followed by one horizontal reading (Figs. 8b and 8c). The sum of both (Fig. 8d) was the identified as potential fake images, requiring a closer consideration. 


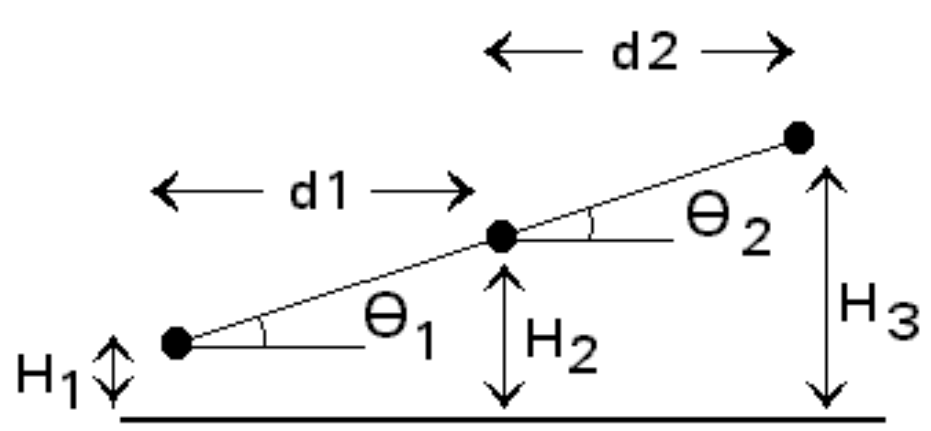

Figure 7 - A close look in the image's points

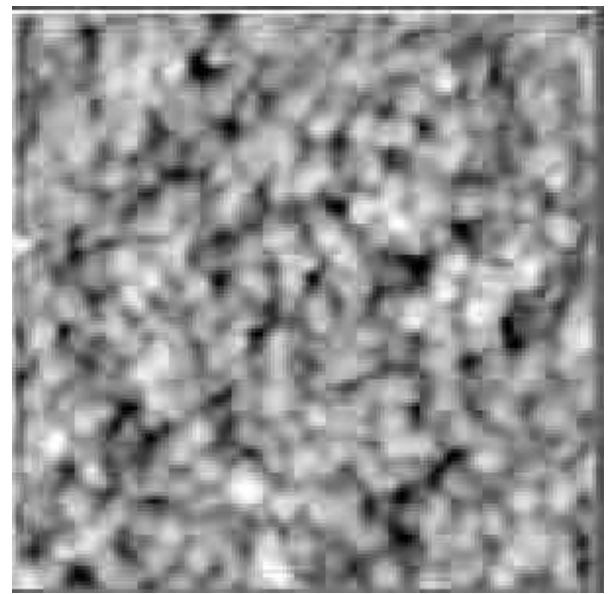

(a)

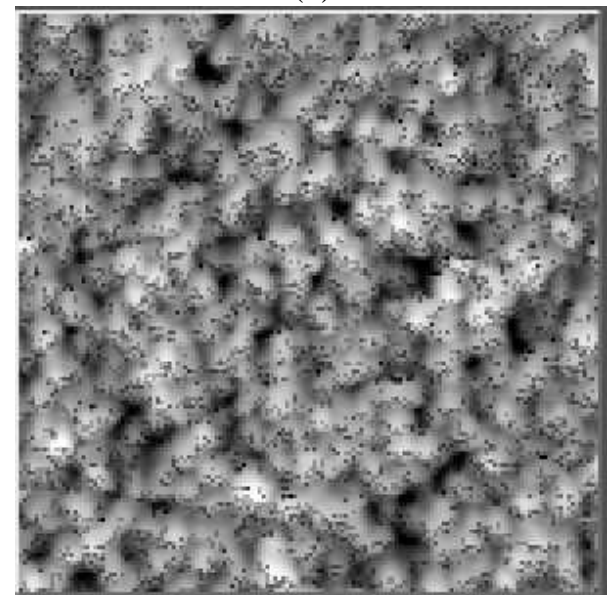

(c)

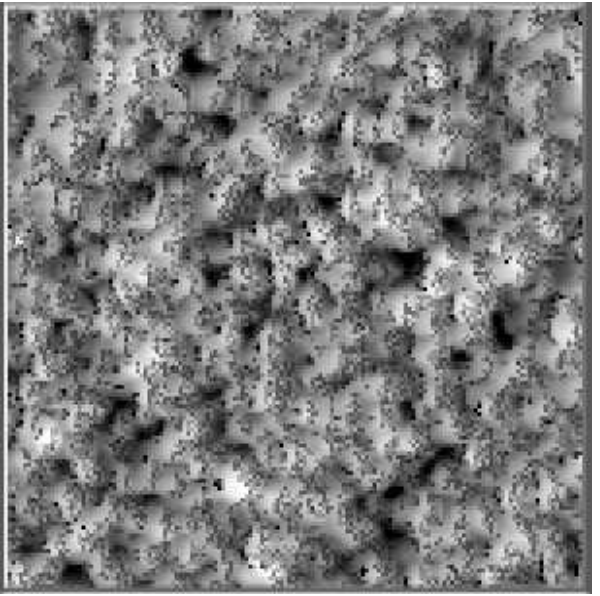

(b)

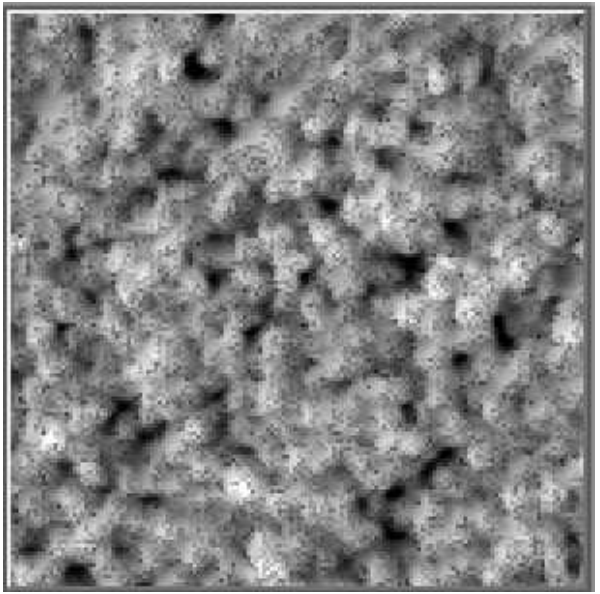

(d)

Figure 8 - A Chitosan thin-film image generated by atomic force microscopy. (a) With no algorithm applied in the image capture. (b) Similar angle identification (black dots) over a horizontal scans. (c) Angle identification over vertical scan and (d) in both directions. 
Such information was quite relevant in microscopic analysis, especially in biological samples observation. Most of thin biological films or small species underwent distortions or change surface topography after chemical interaction, such as metal complexation or enzymatic or mechanical actions. An accurately evaluation of such modification was ordinarily hard to be detected. The developed algorithm could be feasible be used to a previously reference of surface actual topography reducing the events of uncertainties.

\section{CONCLUSIONS}

Images acquired by atomic force microscopy may not always produce topography that accurately reflects the sample because of interaction between tip and scanned sample. A simple algorithm is proposed that can identify potentials artifact regions. We have presented an example application in a polysaccharide film that could illustrate the effectiveness of the proposed methodology.

\section{ACKNOWLEDGMENTS}

The authors acknowledge support from $\mathrm{CNPq}$ (Rede de Nanobiotecnologia) and Embrapa.

\section{RESUMO}

Um aspecto limitante a plena interpretação de imagens geradas por microscopia de força atômica é a interação entre a superfie varrida e ponta de varredura do sistema gerando artefatos de imagens. Para a identificação desses artefatos, propomos neste texto, um algoritmo simples capaz de assinalar esse tipo de irregularidade de imagem. A medida tem por princípio a identificação de ângulos similares formados entre dois pontos sobre a espécie varrida. $\mathrm{O}$ potencial de aplicação do método proposto é aqui ilustrado sobre um filme de polissacarídeo quitosana. As imagens geradas são comparadas entre si, indicando regiões de artefatos típicos gerados pela ponta de varredura. Este algoritmo apresenta-se como uma ferramenta útil a cientistas e usuários, permitindo a separação de aspectos reais e artificiais, que são fundamentais para uma melhor caracterização e medida.

\section{REFERENCES}

Arfken, G. B.; Weber, H. and Weber, H, J. (2000), Mathematical Methods for Physicist. $5^{\text {th }}$ ed. New York : Academic Press. 1112 pp.

Assis, O.B.G.; Bernardes-Filho, R. and Colnago, L. A. (1988), AFM Characterization of Self-Assembled Protein Thin Film on non-flat Substrate. In: International Conference on Electron Microscopy, 14., Int. of Physics Publ. London. (H.A.C. Benevides and M.J. Yacamán eds), Cancún, Mx, Oct. 1998, Symposium AA, vol II. Proceedings... pp. 851-852.

Assis, O. B. G.; Bernardes-Filho, Vieria, D. C. and Campana-Filho, S. P. (2002), AFM Characterization of Chitosan Self-Assembled Films. Intern. J. of Polymeric Materials, 51 : (7), 633 - 638.

Bernardes-Filho, R.; Osiro, D. and Colnago, L. A. (1997), Preparação de amostras de DNA em vidro e mica para realização de medidas de microscopia de força atômica. EMBRAPA-CNPDIA, São Carlos, Pesquisa em Andamento, 6p. Available in: http:// www.cnpdia.embrapa.br.

Deuchi, K.; Kanauchi O. and Imasato Y.. (1994), Decreasing Effect of Chitosan on the Apparent Fat Digestability by Rats Fed on a High-Fat Diet. Biosci. Biotech. Bioch., 58 : (9), 1613-1616.

Drake, B.; Prater, C. B.; Weisenhirn, A. L.; Gould, S. A. C.; Albretch, T. R.; Quate, C. B.; Cannell, D.S.; Hansma, H.G. and Hansma, P. K. (1989), Imaging crystal, polymers, and process in water with the atomic force microscope. Science, 243, 1586-1589.

Erlandsson, R.; Elwing, H.; Eriksson, M.; Olsson, L.; Tengvall, P.; Wigren, R.; Welin-Klintström S. and Lundström, I. (1992), Scanning Force Microscopy Examples of applications to surface chemistry. Colloid and Polymer Science, 88, 154-161.

Herrmann, P. S. P.; Silva M. A. P.; Bernardes Filho, R.; Job, A. E.; Colnago L. A.; Frommer J. E. and Mattoso L. H. C. (1997), Microscopia de varredura por força atômica: uma ferramenta poderosa no estudo de polímeros. Polímeros: Ciência $e$ Tecnologia, 7, 51-61.

Hansma, H. G.; Kim K. J.; Laney D. E.; Garcia R. A.; Argaman M. and Parsons S. M. (1997), Properties of biomolecules measured from atomic force microscope images: a review. Journal of Struct. Biol. 119, 99-108.

Kasas, S., Thomson N. H.; Smith B. L.; Hansma P. K.; Miklossy J. and Hansma H. G. (1997), Biological applications of the AFM: from single molecules to organs. Int. J. Imaging Systems and Technology. 8, 151-161. 
Kanauchi, K.; Deuchi, K.; Imasato, Y.; Shizukuishi, M. and Kobayashi, E. (1995), Mechanism for the inhibition of fat digestion by Chitosan, Bosci Biotechnol Biochem., 59 : (5), 786-90.

Nettles, D. and Elder, S. (2001), Evaluaton of chitosan as a cell scaffold for cartilage tissue engineering. In Proceedings of The $47^{\text {th }}$ Annual Meeting of Orthopedic Research Society, Feb. 25-28, San Francisco, p.202.

Odin, C.; Aime, J. P.; El Kaakour, Z. and Bouhacina T. (1994), Tip's finite size effects on atomic force microscopy in the contact mode: simple geometrical considerations for rapid estimation of apex radius and tip angle based on the study of polystyrene latex balls. Surf. Science, 317 : (3), 321-340

Shao, Z.; Mou, J.; Czajkowsky, D. M.; Yang, J. and Yuan, J. (1996), Biological Atomic Force Microscopy: What Is Achieved and What Is Needed, Advances in Physics, 45, 1-7.

Siperko, L. M. and Landis, W. J. (1993), Atomic Force Microscope Imaging of Biologically Important Materials. In: Atomic-Scale Imaging of Surfaces and Interfaces (Biegelsen, D.K., et al editors) MRS, Symposium Proceedings, Pittsburgh, Pensylvania, v. 295 , p. $243-246$.

Tesini, R. G.; Bernardes Filho, R. and Assis, O.B.G. (1998), Algorithm for Artifacts Identification in Atomic Force Microscopy Images Caused by the Tip Finite Size, Acta Microscopica, 7 : (Suppl. A), 221-224.

Vesenka, J.; Marsh, T.; Miller, R. and Henderson, E. (1996), Atomic force microscopy reconstruction of G-wire DNA. J. Vac. Sci. Technol. B14 : (12), 1413-1417.

Weisenhorn, A. L. (1989), Forces in atomic force microscopy in air and water. Appl. Phys. Lett. 54 : (26), 2651-2653. 